\title{
Concealment of Facts Forestalling an Investigation in Denaturalization Proceedings
}

Section 340(a) of the Immigration and Nationality Act of 1952 provides that a naturalized citizen can be denaturalized ${ }^{1}$ if naturalization was "illegally procured or . . . procured by concealment of a material fact or by willful misrepresentation."2 In recent years, courts have disagreed as to the precise standard of materiality appropriate in proceedings under this section. ${ }^{3}$ There is no doubt that a suppressed fact is material if it would have justified denial of naturalization. ${ }^{4}$ In some cases, however, a concealed fact, although not sufficient in itself to justify denial of naturalization in the initial proceeding, might have led to the discovery of other facts that would have justified denial.

The current dispute concerns the precise meaning of "material fact" in this context. Courts taking divergent positions on this issue have relied on Chaunt $v$. United States, ${ }^{5}$ a 1960 Supreme Court decision construing "material fact" in a somewhat different

1 Only naturalized citizens can lose their citizenship through denaturalization, "a judicial process premised on impropriety in the naturalization." 3 C. GoRdoN \& H. RosenfreLd, Immigration Law and Procendre § 20.1 (1979). Any citizen can, however, be expatriated. Id. The grounds for expatriation are codified at 8 U.S.C. § 1481(a)(1) (1976) (obtaining naturalization in a foreign state); $i d$. $\$ 1481$ (a)(2) (swearing allegiance to a foreign country); id. $\S 1481(\mathrm{a})(3)$ (foreign military service); id. § 1481(a)(4) (employment by foreign government that requires either naturalization or an oath of allegiance); id. § 1481(a)(5) (Supp. II 1978) (formal renunciation of nationality before U.S. officer in a foreign state); id. $\S 1481$ (a)(6) (Supp. II 1978) (formal written renunciation in the U.S.); id. § 1481(a)(7) (Supp. II 1978) (treason).

2 Immigration and Nationality Act of 1952, ch. 477, $\$ 340(\mathrm{a}), 66$ Stat. 260, as amended by Act of Sept. 3, 1954, ch. 1263, § 18, 68 Stat. 1232 and Act of Sept. 26, 1961, Pub. L. No. $87-301, \S 18(a), 75$ Stat. 656 (codified at 8 U.S.C. $\$ 1451$ (a) (1976)).

3 Although section 340(a) uses the word "material" only in connection with concealment ("procured by concealment of a material fact or by willful misrepresentation"), it is undisputed that a "willful misrepresentation" must be of a material fact in order to present a ground for denaturalization. Indeed, no court ever has drawn a distinction between concealment and misrepresentation.

- See, e.g., Chaunt v. United States, 364 U.S. 350, 355 (1960); United States v. Fedorenko, 455 F. Supp. 893, 915 (S.D. Fla. 1978), rev'd on other grounds, 597 F.2d 946 (5th Cir. 1979), cert. granted, 100 S. Ct. 1013 (1980); United States v. Bimba, 233 F. Supp. 966, 971 (E.D.N.Y. 1964).

s 364 U.S. 350 (1960). 
context. Some lower courts require the Government to demonstrate that nondisclosure of the fact frustrated the Government's effort to uncover all relevant information by forestalling an investigation that might have revealed information warranting denial of citizenship. ${ }^{6}$ Other courts require proof that an investigation would have revealed facts sufficient to warrant denial of naturalization.? Thus, one set of courts requires that the Government prove the existence of facts sufficient to warrant denial of naturalization-referred to in this comment as an existing-facts standard of materiality. Other courts consider it sufficient for the Government to show that the forestalled investigation might have revealed such facts-a possible-facts standard of materiality. ${ }^{8}$

This comment considers whether either of these standards is appropriate in denaturalization proceedings under section 340(a). It first reviews the pre-Chaunt law on materiality, which the comment concludes does not assist in resolving the dispute. Since the courts have invoked Chaunt to support the use of both standards, the comment analyzes that decision and the various ways in which the lower courts have attempted to resolve its ambiguous language. This analysis indicates that the Chaunt decision provides little guidance. The two standards are then examined in policy terms and a serious practical flaw is found in each: the existing-facts standard invites perjury, while the possible-facts standard can lead to denaturalization for reasons unrelated to qualifications for citizenship. The comment proposes that the competing policy considerations can be given effect, and the current controversy resolved, by shifting the burden of proof from the Government to the defendant once the Government has met the possible-facts standard of materiality.

- See United States v. Fedorenko, 597 F.2d 946, 950-51 (5th Cir. 1979), cert. granted, 100 S. Ct. 1013 (1980); United States v. Oddo, 314 F.2d 115, 118 (2d Cir.), cert. denied, 375 U.S. 833 (1963).

7 See La Madrid-Peraza v. Immigration \& Naturalization Serv., 492 F.2d 1297, 1298 (9th Cir. 1974) (dictum) (per curiam); United States v. Fedorenko, 455 F. Supp. 893, 914-16 (S.D. Fla. 1978), rev'd, 597 F.2d 946 (5th Cir. 1979), cert. granted, 100 S. Ct. 1013 (1980). See also United States v. Rossi, 299 F.2d 650, 652-54 (9th Cir. 1962) (standard applied in analogous situation-Government required to prove that if the applicant had stated that he was Italian, his entry would have been denied).

s Under this standard, the Government need only show the possibility that facts warranting denial of naturalization exist. 


\section{The Law Before Chaunt}

Prior to 1952, the statute governing denaturalization proceedings did not refer to concealment or misrepresentation of a material fact by an applicant for naturalization. Instead, it provided that the Government could sue to revoke naturalization "on the ground of fraud or on the ground that such order and certificate of naturalization were illegally procured." Fraud, however, was interpreted as the concealment or misrepresentation of a material fact. ${ }^{10}$

None of the pre-1952 denaturalization cases required the Government to prove the existence of the alleged facts or that the facts, if true, were sufficient to warrant disqualification. These cases, however, should not be interpreted as endorsing the possible-facts standard. The courts were never confronted with the question whether the Government must prove the existence of facts that warranted denial of naturalization, or merely prove that such facts might have been obtained but for the forestalled investigation. A typical formulation of the materiality rule from this period provided that the Government had met its burden if it demonstrated that it and the original naturalization court had been denied the opportunity to learn facts relevant to the applicant's qualifications for citizenship. ${ }^{11}$ The Chaunt opinion indicates that the facts alleged, whether or not they exist, must be such as would warrant denial of naturalization. ${ }^{12}$ The remaining

- Nationality Act of 1940, ch. 876, $\S 338,54$ Stat. 1158 (repealed 1952). See also Act of June 29, 1906, ch. 3592, § 15, 34 Stat. 601 (repealed 1940).

${ }^{10}$ See, e.g., United States v. Montalbano, 236 F.2d 757, 760 (3d Cir.), cert. denied, 352 U.S. 952 (1956); Corrado v. United States, 227 F.2d 780, 784 (6th Cir. 1955), cert. denied, 351 U.S. 925 (1956); United States v. Accardo, 208 F.2d 632 (3d Cir. 1953), aff'g per curiam 113 F. Supp. 783 (D.N.J. 1953), cert. denied, 347 U.S. 952 (1954); United States v. Etheridge, 41 F.2d 762, 764 (D. Or. 1930). Although some of these cases were decided after the 1952 amendments, they were litigated under the 1940 Act. See Immigration \& Nationality Act of 1952, ch. 477, $\S 405,66$ Stat. 280 , reprinted in 8 U.S.C. $\S 1101$, at 23 (1976).

"See cases cited note 10 supra.

12 In Chaunt, the Supreme Court held that the Government must show either that the suppressed facts "would have warranted denial of citizenship" or that their disclosure might have led to an investigation that could have led "to the discovery of other facts warranting denial of citizenship." Chaunt v. United States, 364 U.S. 350, 355 (1960). Thus, without regard to whether the Government must prove the existence of facts warranting denial of citizenship, the facts alleged must be sufficient to warrant denial of citizenship. In United States v. Fedorenko, 597 F.2d 946 (5th Cir. 1979), cert. granted, 100 S. Ct. 1013 (1980), for example, the Government alleged that the defendant had concealed facts that would have led to the discovery that he had been a prison guard at Treblinka, a Nazi death camp. Id. at 953. Under Chaunt, denaturalization is appropriate only if the defendant would have been denied naturalization if the naturalization court had known he was a guard at such a place. 
issue-whether the Government must prove the existence of such facts-was never addressed by the pre-1952 case law.

In 1952, Congress rewrote the law of immigration and naturalization, ${ }^{13}$ changing (among other things) the language used to describe the denaturalization standard. As a result, a citizen is now subject to denaturalization if his naturalization was "procured by concealment of a material fact or by willful misrepresentation."14 In substituting this language for the fraud standard, Congress did not intend to change the substantive standard of materiality. Congress was aware that "fraud" had been construed by the Immigration and Naturalization Service as misrepresentation or concealment of material facts. ${ }^{15}$ It deleted the word "fraud" to eliminate confusion and to confirm that "intrinsic fraud" (false swearing in the naturalization proceedings) permitted denaturalization. ${ }^{16}$ Like

There remains, however, the question whether the Government must prove that Fedorenko was a prison guard at Treblinka or whether the Government need only show that it is possible he was a Treblinka guard.

is See Immigration \& Nationality Act of 1952, ch. 477, $\S 1$ 1-360, 66 Stat. 163 (current version at 8 U.S.C. $\$ \S 1101-1503$ (1976)).

14 Immigration \& Nationality Act of $1952, \S 340,8$ U.S.C. $\$ 1451$ (a) (1976). Prior to 1952, the Immigration and Nationality Act included "illegal procurement" as a ground for denaturalization. See Nationality Act of 1940, ch. 876, § 338, 54 Stat. 1158, 1159 (repealed 1952). This basis for denaturalization was not included in the 1952 legislation, but was reestablished in 1961, see text and note at note 2 supra. Illegally procured naturalization occurs when "some statutory requirement which is a condition precedent to naturalization is absent at the time the petition was granted." H.R. REP. No. 1086, 87th Cong., 1st Sess. 39 (citation omitted), reprinted in [1961] U.S. Code CoNG. \& AD. News 2950, 2983. The reinclusion of the illegal-procurement provision was the result of congressional judgment that such a provision was necessary for enforcing the statutory citizenship requirement. See id., reprinted in [1961] U.S. CODE CoNG. \& AD. NEws 2950, 2983. The provision permitting denaturalization for concealment of material facts or willful misrepresentation is often too difficult for the Government to satisfy. Consider, for example, a person who belongs to a subversive organization. Such membership precludes the individual from becoming naturalized. 8 U.S.C. $\S \S 1424,1427$ (1976). If the individual is naturalized despite the membership, the Government, to obtain denaturalization under the concealment-or-misrepresentation provision, must demonstrate that the defendant was aware of the subversive objectives of the organization.

Whether "illegal procurement" is a ground for denaturalization may nevertheless be of little practical significance. One authority has noted that "[p]revailing judicial or administrative attitudes make it unlikely that a denaturalization suit will be brought on a charge of illegal procurement, unless it is coupled with a charge of concealment or misrepresentation. However, flagrant omissions to comply with significant requirements, substantive or procedural, would justify a denaturalization suit." 3 C. GoRDON \& H. RosenrieLd, supra note $1, \S$ 20.4c, at 20-20.

${ }^{15}$ See S. REP. No. 1515, 81st Cong., 2d Sess. 756 (1950).

16 See id. at 769. Prior to the 1952 Act, some courts thought fraud included only "extrinsic" fraud (such as concealing witnesses). United States v. Kusche, 56 F. Supp. 201, 218 (S.D. Cal. 1944). Other courts included "intrinsic" fraud as well. See, e.g., United States v. 
the prior case law, neither the language of the amended statute nor the relevant legislative history indicates whether the Government must prove existence of facts sufficient to warrant denial of naturalization.

\section{Chaunt v. United States}

\section{A. The Facts and the Opinion}

Chaunt $v$. United States, ${ }^{17}$ decided in 1960 , is the only case in which the Supreme Court has considered the materiality standard of section $340(a)$. Chaunt had failed to disclose three prior arrests for petty offenses in his naturalization application. ${ }^{18}$ The Government argued that the arrests were material because, had they been disclosed, the Immigration Service would have investigated and might have discovered that the defendant was (as one witness testified) a district organizer for the Communist Party. ${ }^{19}$

Chaunt argued for a strict standard of materiality: that naturalization would not have been obtained had the concealed or misrepresented facts been known. This, Chaunt argued, can only happen in two situations: when the suppressed facts would have justified denial of citizenship, or when disclosure of the true facts would have led to the discovery of other facts that would have justified denial of citizenship. ${ }^{20}$

Hauck, 155 F.2d 141, 143 (2d Cir. 1946).

Courts agree that the 1952 amendment was not intended to change the substantive standard of materiality. See, e.g., Costello v. United States, 365 U.S. 265, 271 n.3 (1961); United States v. Galato, 171 F. Supp. 169, 173 (M.D. Pa. 1959); United States v. Chandler, 152 F. Supp. 169, 177 (D. Md. 1957); United States v. Lumantes, 139 F. Supp. 574, 575 (N.D. Cal. 1955), aff'd per curiam, 232 F.2d 216 (9th Cir. 1956).

The Senate Report notes that, in addition to making it clear that false statements are a ground for denaturalization, the new standard (concealment of a material fact or willful misrepresentation) would be more easily proved than the standard of fraud or illegality. $S$. REP. No. 1515, 81st Cong., 2d Sess. 769 (1950).

17364 U.S. 350 (1960).

18 Id. at 351-52. The arrests were for distributing handbills, for making a speech outside a church, and for general breach of the peace. Id. at 352.

${ }^{19}$ Id. at 354. The complaint also charged that Chaunt had falsely denied membership in the Communist Party, and that he lacked the requisite allegiance to the Constitution and intent to renounce foreign allegiance. Neither the court of appeals nor the Supreme Court considered these allegations. Id. at 351.

${ }^{20}$ Brief for Petitioner at 11, Chaunt v. United States, 364 U.S. 350 (1960). See id. at 1115; Petition for Writ of Certiorari at 10-11; Petitioner's Reply to Opposition to Petition for Certiorari at 3-4. Chaunt argued that a similar rule obtained in deportation, perjury, and relief from final judgment. Brief for Petitioner at 12-13. See also note 59 infra.

Chaunt repeatedly cited United States v. Anastasio, 226 F.2d 912 (3d Cir. 1953), cert. denied, 351 U.S. 931 (1956), and United States v. Kessler, 213 F.2d 53, 58 n.9 (3d Cir. 1953), 
Before considering the facts of Chaunt, the Supreme Court noted that the appropriate standard must balance competing policy considerations. ${ }^{21}$ The Government and the naturalization court have a compelling need for truthful answers in naturalization proceedings: "Complete replies are essential so that the qualifications of the applicant or his lack of them may be ascertained."22 "On the other hand," observed the Court, "in view of the grave consequences to the citizen, naturalization decrees are not lightly to be set aside-the evidence must indeed be 'clear, unequivocal, and convincing' and not leave 'the issue . . . in doubt." "2s

In applying these considerations to the case, the Court first stated that the arrests themselves were not adequate grounds for denial of citizenship. ${ }^{24}$ Moreover, the Court found unconvincing the Government's contention that disclosure of the arrests would have provoked an investigation that might have revealed Chaunt's communist connections. ${ }^{25}$ Chaunt's naturalization application disclosed a close affiliation with the International Workers' Order, an organization allegedly controlled by the Communist Party. ${ }^{28}$ If the Government had been inclined to search out possible communist connections, reasoned the Court, it surely would have investigated this "much less tenuous and speculative nexus" with the Party. ${ }^{27}$ Given the Government's failure to investigate Chaunt's association with the International Workers' Order, failure to disclose the arrests was "neutral." "28 The Court concluded that "the Government had failed to show by 'clear, unequivocal, and convincing' evidence either (1) that facts were suppressed which, if known, would have warranted denial of citizenship, or (2) that their disclosure might have been useful in an investigation possibly leading to the discov-

to support the proposition that a citizen can be denaturalized only if the suppression affected the naturalization result. E.g., Brief for Petitioner at 12. The cases, however, do not support this position. In Anastasio, the court noted that the Government knew independently of the facts concealed, and hence concluded that no Government inquiry was frustrated by the concealment, 226 F.2d at 917-18. The cited footnote in Kessler was dictum; the court held that the defendant had not responded untruthfully to the application question. 213 F.2d at 58.

21364 U.S. at $352-53$.

22 Id. at 352.

${ }^{23}$ Id. at 353 (quoting Schneiderman v. United States, 320 U.S. 118, 125, 158 (1943)).

See also Baumgartner v. United States, 322 U.S. 655, 670 (1944).

24364 U.S. at 353-54. See note 18 supra.

25364 U.S. at 354-55.

28 Id. at 355 .

27 Id.

${ }^{28} I d$. 
ery of other facts warranting denial of citizenship."29

\section{B. Conflicting Interpretations of the Opinion}

After Chaunt, lower courts continued to agree that a misrepresentation or concealment is material when the suppressed facts themselves would justify denial of naturalization. ${ }^{30}$ Since the decision, however, controversy has existed over the meaning of the second branch of the Chaunt test-that "disclosure might have. been useful in an investigation possibly leading to the discovery of other facts warranting denial of citizenship." Some courts relying on Chaunt have concluded that a misrepresentation or concealment is material if it blocks a path of government investigation that might have led to information warranting denial of naturalization. ${ }^{31}$ Other courts have read Chaunt as setting a stricter standard: the Government must show not only that an investigation could have occurred, but also that it would have uncovered facts warranting denial of citizenship. ${ }^{\mathbf{3 2}}$

In United States v. Fedorenko, ${ }^{33}$ the district court concluded that the Government must prove the existence of facts sufficient to warrant denial of naturalization. The court based this conclusion on an analysis of the grammar and structure of the language used by the Chaunt Court. Under the second branch of the Chaunt test, concealed facts are material if "their disclosure might have been

29 Id. Justice Clark, joined by Justices Whittaker and Stewart, dissented. Justice Clark concluded that Chaunt's concealment prevented the government from conducting an investigation, and that the concealment was, therefore, material under the standard enunciated by the majority. Although agreeing with the decision of the court of appeals (holding that a lie that might have resulted in disqualification was material), Clark considered almost any lie material regardless of its effect on a potential investigation, because "that act of deliberate falsification before an officer of the Government clearly relates to the petitioner's general moral character." Id. at 358 (Clark, J., dissenting).

so See, e.g., United States v. Fedorenko, 455 F. Supp. 893, 915 (S.D. Fla. 1978), rev'd on other grounds, 597 F.2d 946 (5th Cir. 1979), cert. granted, 100 S. Ct. 1013 (1980).

s1 See United States v. Fedorenko, 597 F.2d 946, 951 (5th Cir. 1979), cert. granted, 100 S. Ct. 1013 (1980); United States v. Oddo, 314 F.2d 115, 118 (2d Cir. 1963) (dictum), cert. denied, 375 U.S. 833 (1963); United States v. Bimba, 233 F. Supp. 966, 971-73 (E.D.N.Y. 1964). The Oddo and Bimba courts cited pre-Chaunt cases on materiality as support, 314 F.2d at 118; 233 F. Supp. at 973.

${ }^{32}$ See La Madrid-Peraza v. Immigration \& Naturalization Serv., 492 F.2d 1297, 1298 (9th Cir. 1974) (per curiam) (dictum); United States v. Fedorenko, 455 F. Supp. 893, 914-16 (S.D. Fla. 1978) (alternative ground), rev'd, 597 F.2d 946 (5th Cir. 1979), cert. granted, 100 S. Ct. 1013 (1980). See also United States v. Rossi, 299 F.2d 650, 652-54 (9th Cir. 1962) (analogous context).

${ }^{33} 455$ F. Supp. 893, 915-16 (S.D. Fla. 1978), rev'd, 597 F.2d 946 (5th Cir. 1979), cert. granted, 100 S. Ct. 1013 (1980). 
useful in an investigation possibly leading to the discovery of other facts warranting denial of citizenship." ${ }^{34}$ The Fedorenko court noted that the meaning of the quoted language turns on whether the word "possibly" modifies the entire following phrase, or only part of it. According to "proper grammatical interpretation," said the court, "possibly" modifies only "leading."38 Although the Government need only show that an investigation possibly would have taken place, the Government must prove the existence of facts that would have warranted denial of naturalization. ${ }^{36}$ The court concluded that, had the Chaunt Court intended to adopt a test of materiality more liberal than the existing-facts standard, it could have used clear language to do so. ${ }^{37}$

The weakness in the reasoning of the Fedorenko court is that, just as the Chaunt Court could have used clear language to express a more liberal standard, it also could have done so to express an existing-facts standard. Indeed, the very imprecision of the language suggests that the Court did not choose between competing standards. Imprecise language should not be interpreted as adoption of a specific standard.

The district court's conclusion in Fedorenko that Chaunt established an existing-facts standard of materiality was reversed by the Fifth Circuit, ${ }^{38}$ which held that the Supreme Court meant to adopt a possible-facts standard. The Government need show only that the forestalled investigation might have led to other facts relevant to the naturalization decision; it need not prove the existence of facts sufficient to warrant denaturalization. ${ }^{30}$ The Fifth Circuit based this conclusion on an analysis of the ambiguous passage in Chaunt and on other language in the decision.

The court of appeals assumed that the two branches of the Chaunt test express alternative standards. Under the first branch, denaturalization is appropriate if the defendant suppressed facts sufficient to warrant denaturalization. ${ }^{10}$ Under the second branch, denaturalization is appropriate if the defendant suppressed facts whose "disclosure might have been useful in an investigation possibly leading to the discovery of other facts warranting denial of citi-

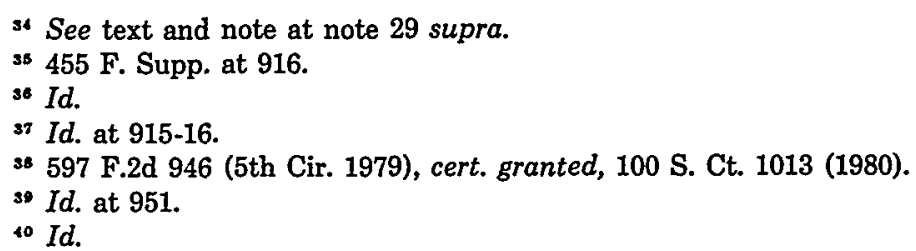


zenship."41 Under the first branch, the Government must show ultimate facts warranting denial of citizenship. The court observed that to construe the second branch as imposing a strict standard would be to replicate the first branch by requiring proof of ultimate facts warranting denial. The court's analysis, however, overlooks the fundamental difference between the two branches of the Chaunt test. The first branch reaches cases in which the facts suppressed by the applicant justify denial of citizenship. The second branch applies to cases in which other facts might have come to light but for the applicant's dishonesty. Hence, the second branch necessarily reaches a significant class of applicants untouched by the first: those who suppress facts, innocent in themselves, but that could lead to more damning information.

The Fifth Circuit drew on other language in Chaunt to support its interpretation of Chaunt's two-pronged test. ${ }^{42}$ Early in the opinion, the Chaunt Court stated: "Suppressed or concealed facts, if known, might in and of themselves justify denial of citizenship. Or disclosure of the true facts might have led to the discovery of other facts which would justify denial of citizenship."13 The court of appeals interpreted this passage as indicating that the Government need not prove the existence of "other facts" sufficient to justify denial. In so doing, the Fifth Circuit failed to consider the context in which the statement was made. The Chaunt opinion surveyed the complex policy considerations involved in denaturalization; the quoted passage closed a paragraph discussing the need for honesty in naturalization proceedings. ${ }^{44}$ The Court also considered the other half of the balance; the next paragraph stated the gravity of denaturalization and the consequent need to protect the citizen-defendant. ${ }^{45}$ Thus, it would not have been remarkable for the test ultimately applied to the case to be more generous to the defendant than was the description of the relevant governmental interests. This language, therefore, does not identify the precise balance struck by, the Court after weighing the competing policy considerations.

\footnotetext{
41 Chaunt v. United States, 364 U.S. 350, 355 (1960).

${ }^{42} 597$ F.2d at 951. See also United States v. Oddo, 314 F.2d 115, 118 (2d Cir. 1963).

4s Chaunt v. United States, 364 U.S. at 352-53.

4 For the quoted passage, see note 50 infra.

45364 U.S. at 353.
} 


\section{The Narrow Holding}

The divergence of the interpretations of the Chaunt opinion is not surprising; the Court did not attempt to state a definitive standard. Indeed, the Court did not address-or even mention-the extensive theorizing about materiality in the parties' briefs. ${ }^{48}$ Rather, the decision is based on a narrow factual argument, ${ }^{47}$ one not raised by the briefs of either party. ${ }^{48}$ The Court concluded that the Government failed to establish that it would have made an investigation had the applicant stated the facts truthfully. Accordingly, the Court never reached the question whether the Government must show the existence of facts sufficient to warrant denial of naturalization.

Chaunt, properly interpreted, thus provides no help in resolving the controversy among the lower courts regarding the appropriate standard of materiality for concealed facts that have forestalled investigation. To resolve that controversy, it is important that the conflicting standards now be examined to determine their respective abilities to effectuate competing policy considerations.

\section{A Policy Analysis of the Competing Lower Court STANDARDS}

\section{A. The Existing-Facts Standard}

The existing-facts standard ${ }^{49}$ suffers from the defect of encouraging dishonest applications. Such a defect should not be overlooked, for in Chaunt the Court stressed the need for honesty in naturalization proceedings. ${ }^{50}$

to See Brief for Petitioner at 11-15, Chaunt v. United States, 364 U.S. 350 (1960); Brief for the United States at 27-37; Brief for the United States in Opposition at 14-16; Petition for Writ of Certiorari at 10-11; Petitioner's Reply to Opposition to Petition for Certiorari at $3-4$; text and note at note 20 supra.

17 See text and notes at notes 25-29 supra.

18 Given the posture of the case on appeal, Chaunt could not argue that the suppression of his arrest record was immaterial because his application revealed his association with a communist organization. A victory for Chaunt on appeal would be followed by a remand to consider, among other things, the Government's allegation that Chaunt willfully concealed his communist affiliations. See Chaunt, 364 U.S. at 351,358 ; Brief for Petitioner at 5 n.2. It would be against Chaunt's interests, therefore, to admit on appeal that the organization to which he belonged and for which he worked was a Party front. See also 364 U.S. at 358-59 (Clark, J., dissenting).

10 See text and notes at notes 32-37 supra.

so Acquisition of American citizenship is a solemn affair. Full and truthful response to all relevant questions required by the naturalization procedure is, of course, to be exacted, and temporizing with the truth must be vigorously discouraged. Failure to give 
A standard that does not ease the Government's burden on account of dishonesty creates an incentive to lie. An applicant who fears that some incident in his past may disqualify him from citizenship may conceal in his petition for naturalization all clues that might facilitate its discovery and still obtain citizenship. If the facts concerning the incident are later revealed, the dishonest applicant is in no worse a position than if he had revealed the truth in his application-unless, of course, he is prosecuted for perjury, ${ }^{\text {bI }}$ which has a five-year statute of limitations. ${ }^{52}$

Indeed, through concealment, the dishonest applicant is likely to improve his position: he shifts the burden of proof to the Government. An alien who applies for naturalization bears the burden of "show[ing] his eligibility for citizenship in every respect." contrast, in a denaturalization proceeding it is the Government that must meet the burden of proving that revocation is appropriate by clear, unequivocal, and convincing evidence. ${ }^{54}$ If the dishonest applicant's falsehood is discovered after he has successfully obtained citizenship, the Government must then prove his ineligibility by clear and convincing evidence-and at a later date, when it will be more difficult to obtain evidence. As one court has noted, "if that were the law, an applicant with something to hide would have everything to gain and nothing to lose by lying under

frank, honest, and unequivocal answers to the court when one seeks naturalization is a serious matter. Complete replies are essential so that the qualifications of the applicant or his lack of them may be ascertained. Suppressed or concealed facts, if known, might in and of themselves justify denial of citizenship. Or disclosure of the true facts might have led to the discovery of other facts which would justify denial of citizenship.

Chaunt v. United States, 364 U.S. 350, 352-53 (1960).

${ }^{81}$ Applications for naturalization are made under oath, 8 U.S.C. $\S 1445$ (a) (1976), and hence a lying applicant risks prosecution for perjury. 18 U.S.C. $\S 1621$ (1976). See also note 60 infra.

B2 18 U.S.C. § 3282 (1976).

63 Berenyi v. Immigration \& Naturalization Serv., 385 U.S. 630, 637 (1967).

st When the Government seeks to strip a person of citizenship already acquired, or deport a resident alien and send him from our shores, it carries the heavy burden of proving its case by "clear, unequivocal, and convincing evidence." But when an alien seeks to obtain the privileges and benefits of citizenship, the shoe is on the other foot. $\mathrm{He}$ is the moving party, affirmatively asking the Government to endow him with all the advantages of citizenship. Because that status, once granted, cannot lightly be taken away, the Government has a strong and legitimate interest in ensuring that only qualified persons are granted citizenship. For these reasons, it has been universally accepted that the burden is on the alien applicant to show his eligibility for citizenship in every respect. This Court has often stated that doubts "should be resolved in favor of the United States and against the claimant."

Id. at 636-37 (footnotes and citations omitted). 
oath to the INS."

\section{B. The Possible-Facts Standard}

Although failure to answer all questions fully and truthfully in naturalization proceedings should be discouraged, courts have never adopted a rule requiring denaturalization of every applicant who misstates or conceals the truth. One commentator observed: "Some misstatements are unintentional, innocuous, or irrelevant. Consequently, it is generally agreed that the severe sanction of denaturalization may be invoked only for material misrepresentations or concealments." The language of section 340(a) supports this position; a fact must be "material" before its concealment becomes a ground for denaturalization. ${ }^{57}$

Some lower courts have adopted a standard of materiality under which the Government must prove only that the suppressed facts would have sparked an investigation that might have led to further information warranting denial of citizenship-the possiblefacts standard. ${ }^{88}$ It is not necessary that the Government show existing facts justifying disqualification-only that the applicant blocked a line of inquiry that might have led to facts warranting a denial of naturalization.

It is unlikely, however, that Congress used the term "material misrepresentation" in a manner inconsistent with the use of that term in most other areas of the law. A misrepresentation is usually regarded as material when it has changed or influenced a decision, or when it would have affected the deciston of a reasonable decisionmaker. ${ }^{59}$ The liberal standard adopted by these courts is anom-

ss United States v. Fedorenko, 597 F.2d 946, 951 (5th Cir. 1979), cert. granted, $100 \mathrm{~S}$. Ct. 1013 (1980). Cf. Ganduxe y Marino v. Murff, 183 F. Supp. 565, 567 (S.D.N.Y. 1959) (making same argument in visa context), aff'd, 278 F.2d 330 (2d Cir.), cert. denied, 364 U.S. 824 (1960).

Bs 3 C. GoRdon \& H. Rosenfield, supra note 1 , § 20.4b(2), at 20-13.

s7 8 U.S.C. $§ 1451$ (a) (1976).

${ }^{58}$ See text and notes at notes $31,42-45$ supra.

so In general contract law, for example, a statement is material if the contract would not have been made without it, see, e.g., Columbia-Knickerbocker Trust Co. v. Abbot, 247 F. 833, 857 (1st Cir. 1917), cert. denied, 248 U.S. 558 (1918); Morris v. Ingraffia, 154 Fla. 432, 437, 18 So. 2d 1, 3 (1944); Schoen v. Lange, 256 S.W.2d 277, 281 (Mo. App. 1953), or if it is likely to affect the conduct of a reasonable person, see, e.g., Costello v. Roer, $77 \mathrm{Cal}$. App. 2d 174, 178, 175 P.2d 65, 68 (1946); Schloss v. Metropolitan Life Ins. Co., 177 Md. 191, 202, 9 A.2d 244, 247 (1939); RESTATEMENT OF RESTitution § 8(2) (1937). In insurance law, a fact is material if the policy would not have been issued without the misrepresentation, see, e.g., Brooks Transp. Co. v. Merchants' Mut. Cas. Co., 171 A. 207, 211 (Del. Super. 1933); Mills v. Reserve Life Ins. Co., 335 S.W.2d 955, 958 (Ky. 1960); Crowder v. National Life \& 
alous in finding materiality without any evidence that a reasonable decisionmaker would have been, affected by the misrepresentation. ${ }^{80}$

Accident Ins. Co., 90 S.W.2d 267, 270 (Tex. Civ. App. 1935), or if the truth would naturally have influenced the insurer's judgment, see, e.g., New York Life Ins. Co. v. Kuhlenschmidt, 218 Ind. 404, 420, 33 N.E.2d 340, 347 (1941); Schas v. Equitable Life Assurance Soc'y, 166 N.C. 55, 59, 81 S.E. 1014, 1015 (1914); Perry v. Continental Ins. Co., 178 Wash. 24, 29, 33 P.2d 661, 663 (1934).

A misstatement made to a government agency may be material, depending on the circumstances, if it actually changed the outcome of a government decision, see, e.g., Cartenada-Gonzalez v. Immigration \& Naturalization Serv., 564 F.2d 417, 432 (D.C. Cir. 1977) (labor certificate to alien), if it was likely to affect the decision, see, e.g., Crescent Invs. Co. v. Commissioner of Banking \& Ins., 103 N.J. Super. 11, 19, 246 A.2d 493, 498 (1968) (secondary mortgage license to investment company), or if it was able to affect or had a natural tendency to affect a government action, see, e.g., United States v. McGough, 510 F.2d 598, 602 (5th Cir. 1975) (crime of making false statements to federal agency); Tzantarmas v. United States, 402 F.2d 163, 168 (9th Cir. 1968) (same), cert. denied, 394 U.S. 966 (1969).

In securities law, information is material if it is substantially likely that a reasonable investor would consider it important. See, e.g., TSC Indus., Inc. v. Northway, Inc., 426 U.S. 438, 449 (1976); List v. Fashion Park, Inc., 340 F.2d 457, 462 (2d Cir.), cert. denied, 382 U.S. 811 (1965).

so Only the crime of perjury involves a similar standard. In federal law and in some states, a false statement made at a trial or similar proceeding is considered material in a subsequent perjury prosecution if it was material for purposes of admissibility of evidence-that is, the statement is material if it was offered to prove or disprove a contention as to a direct or collateral issue in the case. See, e.g., Blackmon v. United States, 108 F.2d 572, 573-74 (5th Cir. 1940); United States v. Slutzky, 79 F.2d 504, 506 (3d Cir. 1935); Newman v. United States, 58 F.2d 751, 755 (9th Cir. 1932); State v. Whitlock, 138 Kan. 602, 60506, 27 P.2d 262, 263-64 (1933); State v. Ray, 36 Or. App. 375, 378-79, 584 P.2d 366, 367 (1978). See also McCormick's HandbooK of the LAw or Evidence § 185 (2d ed. 1972). Other states focus instead on possible influence on the factfinder, see, e.g., State v. Fasano, 119 Conn. 455, 460, 177 A. 376, 378 (1935); Williford v. State, 53 Ga. App. 334, 338, 185 S.E. 611, 613 (1936); People v. Brill, 100 Misc. 92, 99, 165 N.Y.S. 65, 69 (Gen. Sess. 1917).

Some state courts apply these standards as well to statements made in grand jury investigations, see, e.g., Darnell v. State, 63 Ga. App. 582, 587, 11 S.E.2d 692, 696 (1940) (tendency to affect outcome); People v. Lev, 91 Misc. 2d 241, 244, 398 N.Y.S.2d 593, 596 (Sup. Ct. 1977) (evidentiary rule). The federal courts in such cases have adopted a standard fairly close to the possible-facts standard, in holding that a false statement is material if it tends to impede or hamper the grand jury's investigation. See, e.g., United States v. Hirsch, 136 F.2d 976, 977 (2d Cir.), cert. denied, 320 U.S. 759 (1943); United States v. Laikin, 439 F. Supp. 257, 259 (E.D. Wis. 1977), rev'd, 583 F.2d 968 (7th Cir. 1978); United States v. Lasater, 403 F. Supp. 208, 216 (W.D. Mo. 1975), aff'd, 535 F.2d 1041 (8th Cir. 1976).

Perjury prosecutions are, however, different in nature from denaturalization proceedings. A perjurer is convicted for his false statement; the lie itself is a crime deserving punishment. Justice Clark, in his Chaunt dissent, took an analogous position in the denaturalization context, arguing that an applicant's lie is itself an indication of unsatisfactory moral character, 364 U.S. at 358 (Clark, J., dissenting). See id. at 360. The Chaunt majority's implicit rejection of this point indicates that denaturalization, unlike conviction for perjury, does not necessarily follow as a consequence of the immoral act of lying. A dishonest applicant for naturalization may be subject to perjury penalties as well as denaturalization. See 
Moreover, this standard discriminates between citizens in a manner inconsistent with the language of the statute and on grounds having nothing to do with their actual qualifications. Consider, for example, two hypothetical naturalized citizens, each of whom has concealed some past event in the mistaken belief that it would harm his chances for obtaining citizenship. The fact suppressed by the first citizen is innocuous. His concealment is not grounds for denaturalization because revelation of the fact would not lead to an inquiry. The fact concealed by the second citizen appears more serious at first sight, and would have provoked an investigation. This hypothetical forestalled investigation is characterized by the court as one that might have led to facts warranting denial of naturalization. If it had actually been carried out, it would not have led to such facts, and would have cleared the citizen of suspicion-an unpredictable outcome given the suspicious attributes of the citizen. Under the possible-facts standard, the second citizen may be denaturalized for concealing a material fact. There is no difference between these two citizens, either in terms of their actual qualifications or in terms of the moral quality of their misstatements. In effect, the second is denaturalized because he is subject to an unwarranted suspicion. Moreover, this result is inconsistent with section 340(a), which provides for denaturalization when naturalization has been "procured" by concealment or misrepresentation..$^{61}$ By hypothesis, the second citizen would have been naturalized even if he had spoken the truth.

\section{A Rebuttable Presumption of Materiality}

The flaws in the two competing standards of materiality are oddly complementary; each standard's flaw is the other's strength. Under the existing-facts standard of materiality, only those persons unworthy of American citizenship are in danger of denaturalization. The weakness of this standard is that it imposes a tremendous burden on the Government and creates incentives for perjury in the initial application. Because the citizen lied in his initial application, the Government must prove by clear and convincing evidence, perhaps many years later, that the applicant was ineligible for citizenship. The possible-facts standard places a lighter burden on the Government and does not create incentives for perjury in

note 51 supra.

${ }^{61}$ See Brief for Petitioner at 11, Chaunt v. United States, 364 U.S. 350 (1960). 
the initial application. Unfortunately, under this standard, a person otherwise fully qualified for citizenship may be denaturalized for making a misstatement having no ultimate bearing on his qualifications.

These limitations could be surmounted, however, by employing the possible-facts standard while adjusting the order and burden of proof in denaturalization proceedings. As under the present possible-facts standard, the Government should bear the initial burden of proving by "clear, unequivocal, and convincing evidence" 62 that the defendant has concealed or misrepresented a fact. Furthermore, the Government should be required to show that the defendant's falsification forestalled an investigation that might have revealed information fatal to his application. The Government should not, however, be required to prove the existence of facts sufficient to warrant denial of citizenship. Instead, the described proof should raise a presumption that the suppressed fact was "material"-meaning that it, together with the fruits of the resulting investigation, would have warranted denial. The burden would then shift to the defendant to rebut the presumption by proving that the investigation could not have uncovered anything so damaging as to justify denial of naturalization.

This procedure would eliminate the vices of the more extreme positions. Once the defendant's misrepresentation is established, his case is returned to roughly the posture that would have existed had he told the truth at the outset-with the burden on the applicant to explain the suspicious circumstances and to show his eligibility for citizenship. ${ }^{63}$ Moreover, it is not unfair that the applicant may have to bear a burden that, because of the passage of time, is heavier than would have existed at the initial proceeding. It is the applicant's concealment that prevented the issues from being handled at the original proceeding. The proposed solution is more likely to preclude application of the harsh penalty of denaturalization to those who in fact deserve their citizenship. ${ }^{64}$ An individual

${ }^{62}$ Schneiderman v. United States, 320 U.S. 118, 125 (1943).

63 See also text and note at note 53 supra.

64 This screening device is imperfect; a defendant who deserves to retain his citizenship may fail to carry his burden of persuasion. To the extent that this failure results from the passage of time, it is the unavoidable cost of encouraging honesty in the naturalization application. If it is not caused by delay, then presumably he could not have proven his eligibility in the original naturalization proceeding had all the facts been known.

Arguably, shifting the burden of proof to the defendant is contrary to Schneiderman v. United States, 320 U.S. 118 (1943), which requires that the Government bear the burden of 
who concealed a fact on his naturalization application is given an opportunity to show that he is, nonetheless, qualified for citizenship.

\section{Conclusion}

In recent years, the courts have been in disagreement as to the appropriate standard of materiality in proceedings under section 340 (a) of the Immigration and Nationality Act of 1952. When it has been alleged that a naturalized citizen, by concealing facts in his application for naturalization, forestalled an investigation, some courts have required that the Government show that the forestalled investigation would have revealed facts warranting denial of naturalization. Other courts have required only that the Government prove that the forestalled investigation might have produced such facts. The statute, pre-Chaunt case law, and Chaunt itself fail to address the precise issue raised in the current dispute. Analysis of the conflicting standards-possible-facts and existing-facts-reveals a serious defect in each. Such defects can be overcome, however, by shifting the burden of proof to the defendant after the Government has shown that the forestalled investigation might have revealed facts warranting denial of naturalization.

Kristin E. Hennes

proof by clear and convincing evidence in denaturalization cases. This argument, however, begs the question. A requirement that the Government prove its case does not give any guidance as to what constitutes the Government's case. 